Nepalese Vet. J. 35:23- 40

\title{
Effect of Non-Genetic Factors on Different Genetic Group of Buck's Semen Quality and Quantity at National Livestock Breeding Center, Nepal
}

\author{
R. Bastola ${ }^{1 *}$, M. R. Kolachhapati ${ }^{2}$, N. A. Gorkhali ${ }^{3}$, R. Poudel ${ }^{4}$, S. Sharma ${ }^{4}$ and S. \\ Sapkota $^{3}$ \\ ${ }^{1}$ Animal Nutrition Division, Nepal Agricultural Research Council, Khumaltar, Lalitpur \\ ${ }^{2}$ Agriculture and Forestry University, Rampur, Chitwan \\ ${ }^{3}$ Animal Breeding Division, Nepal Agricultural Research Council, Khumaltar, Lalitpur \\ ${ }^{4}$ National Animal Breeding center, National Livestock Breeding Center, Pokhara, Kaski \\ *Corresponding author: bastola_rupa@yahoo.com
}

\begin{abstract}
This study was conducted to assess the quality and quantity aspects of different genetic group of buck's semen used for Artificial Insemination (AI) at National Livestock Breeding Centre (NLBC), Pokhara. For this, records from different breeds and genetic groups of buck semen collected over 3 years (2014-2016) were analyzed. Parameters such as volume, density, mass motility, initial motility concentration and post thaw motility were analysed for various non-genetic factors like year, season, green based feeding. Data were analyzed by least square method using Harvey 1990 software package. The result showed that different genetic group of bucks $(P<0.001)$ have highly significant effect $(P=0.00)$ on volume of semen. Significant interaction $(P=0.01,0.001)$ was observed between year and season on volume and density of the semen. Similarly, different genetic group of bucks had significant effect on density ( $P=0.03)$. Year showed a significant effect $(P=0.02)$ on initial motility of the buck semen. Similarly, significant interaction between year and season on initial motility percentage $(P=0.01)$ and post thaw motility percentage $(P=0.00)$ was found. Likewise, year has a significant effect $(P=0.01)$ on the Post thaw motility percentage $(P=0.03)$ of the semen. Also, a significant effect of different breed of buck was found on post thaw motility percentage $(P=0.00)$. In addition, the average post thaw motility percentage semen of all the genetic groups of bucks was above 52\% which is considered as a good percentage for the success of AI. This result might be due to use of egg yolk free extender which is soya-based protein. Moreover, adoption of new buck semen processing technologies might further improve the semen quality and long term storability along with better management and distribution of these buck
\end{abstract}


semen by Government of Nepal through livestock unit at different municipalities will improve the conception rate and save huge effort and investment for the importation of buck semen.

Keywords: Buck; Genetic group, Non-genetic factor; Semen quality

\section{INTRODUCTION}

Nepal's goat population is enormous, being more than 10.17 million in number with an average annual growth rate of $3.67 \%$ from $2001 / 02$ to 2014 (MOAD, 2014). Goat contributes $19.80 \%$ to the total meat production of the nation and ranks in second position after buffalo (58.31\%) with respect to meat production (MoAD, 2013). Though there are 10.25 million goats in the country, but their production is not enough to meet the country demand which encourages large numbers of goats to be imported from bordering countries. Due to indiscriminate breeding and unawareness among the animal owners, the productive and reproductive efficiency of goats' lags behind and need improvement. Establishment of true line breeds with high prolificacy and fast growth are major challenges to be addressed. Selective breeding of goats can be alternating for genetic up gradation.

Artificial insemination (AI) using cryopreserved semen is an important tool for successful implementation of breeding program to establish pure line breed of goat. The success of AI largely depends on quality of cryopreserved semen that in turns determines the conception rate. Male fertility is highly influenced by semen quantity and quality (Mittal et al., 2014). The quality of thawed frozen semen is very important for success of AI. With the objectives of replacing the import of goat from neighboring countries the Directorate of livestock production has initiated the goat mission program to increase the number of AI coverage in goat and to develop a goat resources center in 80 private farms. Understanding the sources of variation in semen quality, early detection of highly fertile bucks and with good quality thawed frozen semen would be of great interest to all livestock breeders (Arredondo et al., 2015). Quality assurance through regular monitoring of semen quality has becomes an important component of freeze-thawing protocol. But there is great challenge during processing and production of buck frozen semen. So, this study will help to evaluate the quality and quantity of semen that are produced at National Livestock Breeding Center (NLBC) and along with non-genetic factor affecting the different parameter of semen. 


\section{MATERIALS AND METHODS}

\section{Study Site}

National Livestock Breeding Center, Pokhara.

\section{Study Design}

Longitudinal descriptive study was conducted during the period of July 2016 to January 2017. Three years data of buck semen quality, collected at National Laboratory Breeding Centre (NLBC), Pokhara were included for the analysis.

\section{Data Collection}

Data on Season, Year, Feed, and Breed (Jamunapari, Sannen, Ajmeri, and Boer) were collected. Regarding semen quality parameters, volume, density, mass motility, initial motility, concentration, post thaw motility was collected. The recorded data were collected based on the following Standard Operating Procedure (SOP) of NLBC.

\section{Collection of Semen}

Semen was collected in the morning between 7- 8 am by Artificial Vaginal (AV) method. The AV consists of outer rubber cylinder, inner rubber line, rubber band, cone and collecting tube. Semen was collected with the help of a teaser animal. All the apparatus used for semen collection was sterilized before collection of semen using autoclave machine. The inner liner temperature of AV was maintained at 42$43^{\circ} \mathrm{C}$ water by loading at $52-54^{\circ} \mathrm{C}$ two-third of its volume. The rest of one-third area of water jacket was filled with air. Before collection of semen some sterile non spermicidal gel was applied into the inner side of artificial vagina by glass rod. The semen collected tube was labeled with the identification of the breed and mouth of the tube was sealed with aluminum foil. The semen containing tube was kept in water bath at $37^{\circ} \mathrm{C}$ for five minutes.

\section{Semen Evaluation}

\section{Volume}

The volume of ejaculates $(\mathrm{ml})$ was recorded from the graduated collection vials. The color and opacity of the semen and presence of any foreign body, such as pus were checked.

\section{Mass Motility}

Mass motility of raw semen was examined by using a drop of raw undiluted semen on a pre-warmed $\left(37^{\circ} \mathrm{C}\right)$ slide under a light microscope at 10x and rated based on the 
Nepalese Vet. J. 35:23-40

swirling currents.

$0=$ no motility

$+=$ Less than 20 percent of the sperm showing progressive motion.

$++=20-40$ percent showing progressive movement but no wave.

$+++=44-60$ percent showing progressive movement but with slow wave.

$++++=60-80$ percent showing progressive movement with rapid wave.

$+++++=80-100$ percent showing progressive movement with rapid wave.

\section{Individual Motility}

One drop of semen was mixed with $2 \mathrm{ml}$ of diluter. The composition of Diluter is given in annex. Then the individual motility of diluted semen was examined by using a drop of diluted semen on a pre-warmed $\left(37^{\circ} \mathrm{C}\right)$ slide covered with cover slip. Slide was examined under a light microscope at 20x and rated based on the forward movement of the individual sperm.

\section{Concentration of Sperm}

The concentration of spermatozoa in semen sample (ten billion/ml) was estimated by using Semen photometer SDM6 of Minitube Company.

\section{Procedure}

$35 \mu \mathrm{l}$ of buck semen was diluted with $4 \mathrm{ml}$ of normal saline in a cuvette and mixed well with micropipette. Then the cuvette was inserted in sample container of a photometer which was pre-set with the buck semen. Then the reading was shown on the screen.

\section{Dilution of semen}

Andromed R, a readymade diluter of Minitube company was used for dilution of semen. Andromed $\mathrm{R}$ is a soybean lecithin-based extender that has been suggested as a replacement of egg yolk as animal source diluents. The composition of the extender is presented in annex 2 . The volume of diluter required for dilution of semen was calculated by using the following formula. This formula was developed by the NLBC. With the help of auto dispenser required volume of dilution was taken in the beaker and semen was added in it. The beaker was labeled with the identification number and dilution amount. The following formula for calculation of extender was used according to NLBC.

Extender $=$ 


\section{Sealing Filling and Printing of Straw}

Minitube automated filling sealing and printing machine was used for filling sealing and printing of buck semen on the straw. The genuine CASSOU straw of imv technologies and minitube semen straws were used for this purpose. $0.25 \mathrm{ml}$ of semen was filled in each straw. Buck number, breed, date of semen collection was printed on the straw.

\section{Cooling of Straw}

Only filled and sealed straw were used for the cooling and those half-filled and unsealed straw were discarded. The sealed straws were carefully spread over the freezing rack and kept on cooling chamber at $5^{\circ} \mathrm{c}$ for three hours.

\section{Freezing of Straw}

For freezing, the Styrofoam container was filled with liquid nitrogen. The rack carrying semen straws was suspended for 10 min above liquid nitrogen, keeping a gap of $5 \mathrm{~cm}$ between the surface of liquid nitrogen and the semen straws. After 10 min, the straws containing semen were submerged into liquid nitrogen. Then the semen straws from each buck were grouped and loaded into a liquid nitrogen canister and stored in at $-196^{\circ} \mathrm{C}$ for approximately 3 months.

\section{Evaluation of Post Thaw Motility}

Post thaw motility was examined after the semen straws were loaded in the liquid nitrogen canister. Semen straws were thawed, by dipping them into a water bath at $37^{\circ} \mathrm{C}$ for $20 \mathrm{~s}$ before evaluation. Post thaw motility was observed in microscope in $20 \mathrm{xs}$ and in the Computer Assisted Semen Analysis (CASA).

\section{Data Management and Analysis}

The collected data were entered in Microsoft Excel. The variables year, Season, Feed and genetic group were coded numerically and entered. Continuous data volume, concentration, mass motility, initial motility and post thaw motility were entered directly. Data were analyzed using Harvey 1990. Mean, least square mean, standard deviation, coefficient of variation was computed. Inferential statistics were used to compare volume, density, mass motility, initial motility, concentration, post thaw motility among season, year, feed, genetic group. $\mathrm{P}$ value $\leq 0.05$ was considered significant. Linear regression analysis was done of dependent variable volume, density, concentration, mass motility, individual motility, post thaw motility with predictor year, season, feed and genetic groups. 
Nepalese Vet. J. 35:23-40

\section{Model used for analyzing the data}

The fixed effect and random effect models of 'Harvey 1990' statistical package were used to analyze all the observations of collected data.

Model used for analyzing the semen quality (semen volume, semen density, mass activity, sperm concentration, initial motility, pre-filling motility and post thaw motility)

The following fixed effect model was used to express each observation of semen quality produced from breeding Jersey bulls.

$\mathbf{Y}_{\mathrm{ijklmno}}=\boldsymbol{\mu}+\mathbf{a}_{\mathrm{i}}+\mathbf{b}_{\mathrm{j}}+\mathbf{c}_{\mathrm{k}}+\mathbf{d}_{\mathrm{l}}++\mathbf{e}_{\mathrm{ijkl}}$

Where, $\boldsymbol{\mu}$ is the overall mean

$\mathbf{a}_{\mathbf{i}}$ is the effect of $\mathbf{i}^{\text {th }}$ year $(i=2014,2015,2016)$

$\mathbf{b}_{\mathbf{j}}$ is the effect of $\mathbf{j}^{\text {th }}$ season of semen collection ( $k=$ Dry, Wet)

$\mathbf{c}_{\mathbf{k}}$ is the effect of $\mathbf{k}^{\text {th }}$ genetic group buck ( $\mathrm{k}=$ Boer $100 \%$, Sannen, Boer $50 \%$, Boer $75 \%$, Ajmeri , Jamunapari)

$\mathbf{d}_{\mathbf{l}}$ is the effect of $\mathbf{l}^{\text {th }}$ grass base feeding ( $1=$ Teosinte, Oat, Napier)

$\mathbf{e}_{\mathrm{ijkl}}$ is the random element (error mean) assumed to be normally and independently distributed among the sampled population

\section{RESULTS AND DISCUSSION}

The information of semen parameter (volume, density, mass motility, concentration, initial motility and post thaw motility along with the non-genetic factor (year, season, forage and genetic group) affecting these parameters are presented and discussed below. Also, the summary tables of ANOVA for each parameter are shown respectively.

\section{Physical quality parameters}

\section{Semen volume}

The overall volume ( $\mathrm{ml} \pm \mathrm{SE}$ ) of semen produced by different genetic group of bucks was found $1.45 \pm 0.11 \mathrm{ml}$ (Table 1). This finding was higher than other reports (Sultana et al., 2013) and Hassan et al., (2010). Other studies reported that buck semen volume ranges from $0.58 \pm 0.17$ to $1.04 \pm 0.11 \mathrm{ml}$. 


\section{Effect of year on volume and density of semen}

No significant effect $(\mathrm{P}>0.05)$ on volume of semen was found with respect to year of semen collection (Table 1). There was no specification trend of semen volume over three years. Highest semen volume was recorded in the year $2014(1.67 \pm 0.23)$ followed by $2016(1.43 \pm 0.23)$ and $2015(1.23 \pm 0.07)$. Like many other non-genetic factors semen quantity is affected by the frequency of semen collection and favorable temperature which might have affected on the volume of semen quantity. Year showed slight variation in semen density. Accordingly, semen density was found ( $3.20 \pm 0.09)$ in the year 2014 followed by year $2016(3.08 \pm 0.09)$ and 2015(3.06 \pm 0.03$)$.

\section{Effect of season on volume and density of semen}

There was no significant association of season with the volume of the semen. The semen volume was $1.43 \pm 0.15 \mathrm{ml}$ in dry season and $1.46 \pm 0.15 \mathrm{ml}$ in wet season. The result of the present study similar with the findings of Maina et al., (2006). This finding is also supported by the Aguiar et al., 2013 who found the non-significant association of season with volume of the buck semen. However, this result is contradicted with the Elsheikh and Elhammali (2015), Sultana et al., (2013) who found that the season has a significant effect on semen volume of mature crossbred bucks. This result shows that there might be no variation or little variation on environmental factors like temperature, day length, moisture percentage etc. No seasonal effects were found on semen density. Season showed slight variation on semen density. i.e. mean $3.04 \pm$ 0.06 in dry season and $3.19 \pm 0.06$ in wet season.

Table 1: Least square means and standard errors for volume ( $\mathrm{ml})$ and density of buck semen

\begin{tabular}{|l|c|c|c|c|c|}
\hline Factors & $\begin{array}{c}\text { Number } \\
\text { (n) }\end{array}$ & $\begin{array}{c}\text { LS Mean } \pm \\
\text { SE } \\
\text { (Volume) }\end{array}$ & P- value & $\begin{array}{c}\text { LS mean } \pm \\
\text { SE } \\
\text { (Density) }\end{array}$ & P- value \\
\hline Overall mean & 241 & $1.45 \pm 0.11$ & & $3.11 \pm 0.04$ & \\
\hline Year & & & 0.15 & & 0.34 \\
\hline 2014 & 32 & $1.67 \pm 0.23$ & & $3.20 \pm 0.09$ & \\
\hline 2015 & 151 & $1.23 \pm 0.07$ & & $3.06 \pm 0.03$ & \\
\hline 2016 & 58 & $1.43 \pm 0.23$ & & $3.08 \pm 0.09$ & \\
\hline Season & & & 0.92 & & 0.11 \\
\hline Dry (Dec- May) & 109 & $1.43 \pm 0.15$ & & $3.04 \pm 0.06$ & \\
\hline Wet (June-July) & 132 & $1.46 \pm 0.15$ & & $3.19 \pm 0.06$ & \\
\hline
\end{tabular}


Nepalese Vet. J. 35:23- 40

\begin{tabular}{|c|c|c|c|c|c|}
\hline $\begin{array}{ll}\text { Green } & \text { based } \\
\text { forage } & \\
\end{array}$ & & & 0.98 & & 0.14 \\
\hline Teosinte & 89 & $1.47 \pm 0.17$ & & $3.04 \pm 0.07$ & \\
\hline Oat & 46 & $1.43 \pm 0.18$ & & $3.12 \pm 0.07$ & \\
\hline Napier +Maize & 106 & $1.44 \pm 0.11$ & & $3.18 \pm 0.04$ & \\
\hline $\begin{array}{l}\text { Genetic group } \\
* * *\end{array}$ & & & 0.00 & & 0.03 \\
\hline Boer $100 \%$ & 44 & $1.26 \pm 0.28^{\mathrm{bc}}$ & & $2.95 \pm 0.11^{\mathrm{c}}$ & \\
\hline Boer $75 \%$ & 23 & $1.58 \pm 0.15^{\mathrm{c}}$ & & $3.09 \pm 0.06^{\mathrm{a}}$ & \\
\hline Boer $50 \%$ & 29 & $1.48 \pm 0.24^{\mathrm{b}}$ & & $3.22 \pm 0.10^{\mathrm{a}}$ & \\
\hline Sannen & 53 & $1.18 \pm 0.23^{\mathrm{ab}}$ & & $3.35 \pm 0.09^{b}$ & \\
\hline Ajmeri & 39 & $1.21 \pm 0.27^{\mathrm{c}}$ & & $3.02 \pm 0.11^{\mathrm{bc}}$ & \\
\hline Jamunapari & 53 & $1.97 \pm 0.12^{\mathrm{a}}$ & & $3.05 \pm 0.05^{\mathrm{bc}}$ & \\
\hline \multicolumn{6}{|l|}{ Interactions } \\
\hline Year x Season & & & 0.01 & & 0.001 \\
\hline $\begin{array}{l}\text { Year x Genetic } \\
\text { group }\end{array}$ & & & 0.25 & & 0.43 \\
\hline $\begin{array}{l}\text { Season } \mathrm{x} \\
\text { Genetic group } \\
\end{array}$ & & & 0.87 & & 0.61 \\
\hline $\begin{array}{l}\text { Green based } \\
\text { forage x Genetic } \\
\text { group }\end{array}$ & & & 0.45 & & 0.01 \\
\hline
\end{tabular}

* Significant at $5 \%(\mathrm{P}<0.05) ; * *$ Significant at $1 \%(\mathrm{P}<0.01) ;{ }^{* * *}$ Significant at $0.1 \%$ $(\mathrm{P}<0.001)$; NS: Non-significant

\section{Effect of genetic group of bucks on volume and density of semen}

Highly significant effect $(\mathrm{P}<0.001)$ on volume of semen was found with respect to different genetic group of bucks (Table 2). Highest volume of semen was found in Jamunapari breed $(1.97 \pm 0.10 \mathrm{ml})$ followed by Ajmeri $(1.61 \pm 0.12 \mathrm{ml})$, Sannen $(1.38 \pm$ $0.11 \mathrm{ml})$, Boer cross $50 \%(1.29 \pm 0.13 \mathrm{ml})$, Boer $75 \%(1.38 \pm 0.11 \mathrm{ml})$ and Boer $100 \%$ $(1.02 \pm 0.12)$. The maximum average volume of semen in Jamunapari was higher than the report of Hassen et al., who reported the average volume of semen $0.9 \pm 0.2 \mathrm{ml}$ in Jamunapari buck. Similarly, average volume of $0.57 \mathrm{ml}$ of semen in Saanen buck was 
reported by Ferreira et al., 2014 in Brazil which was lower than our findings. (Bezerra 2012) reported the average volume of semen ejaculated in pure Boer was $1.1 \pm 0.4 \mathrm{ml}$ which is similar to our findings but Suyadi 2012 found $0.74 \pm 0.43 \mathrm{ml}$ of semen in pure Boer breed which was lower than our findings. This significant effect $(\mathrm{P}<0.001)$ may be due to the genetic potential, age variation among bucks and genetic potentiality and genetically superior buck could produce higher volume of semen. Older bucks produced higher volume of semen than younger bucks. Waltl et al., (2004) found age of bull had highly significant effect on semen volume (higher the age higher the volume of semen). Significance effect $(\mathrm{P}=0.03)$ of Genetic group on semen density was found. Highest semen density was found in Sannen $(3.35 \pm 0.09)$ followed by Boer 50\% (3.22 \pm 0.10$)$, Boer 75\% (3.09 \pm 0.06$)$, Jamunapari (3.05 \pm 0.05$)$, Ajmeri $(3.02 \pm 0.11)$ and Boer $100 \%(2.95 \pm 0.11)$.

\section{Effect of grass-based feeding on volume and density of semen}

There was no significant effect on the volume of semen with respect to green based forage feed to different genetic group of bucks. Average volume of semen recorded by feeding Teosinte (Euchlaena maxicana) was $(1.47 \pm 0.17 \mathrm{ml})$ followed by Napier and maize $(1.44 \pm 0.11)$ and Oat (Avena sativa) $(1.43 \pm 0.18)$. Similarly, no significant effect on density of semen was found with respect to green based forage feed to different genetic group. Average density of semen of buck feed to Napier and maize was $(3.18 \pm 0.04)$ followed by Oat (Avena sativa) $(3.12 \pm 0.07)$ and Teosinte (Euchlaena maxicana) was (3.04 \pm 0.07$)$.

\section{Interaction of different factors on volume of the semen:}

Significant effect on semen was found with respective to interaction between year and season. Interaction between other factors (Year x Genetic group, Season $x$ Genetic group, and Feed x Genetic group) had no significant effect on the volume of semen production of different genetic group of bucks. Interaction between year and Season showed highly significant $(\mathrm{P}<0.001)$ effect on density of semen. Similarly, interaction between feed and genetic group also showed the significant effect on density of the semen. Interaction between year, season and genetic group showed no significant effect on density of semen.

\section{Mass activity/Mass motility of sperms}

The collective movement of sperms or their wave motion is called as mass activity. Mass activity/Mass motility of sperms in fresh semen was found to be variate (Table 2) due to different genetic group and so many non-genetic factors. 


\section{Effect of year on mass motility and initial motility of sperm}

Mass activity of buck semen was different according to year. Highest mass activity was found in year 2015 followed by year 2016 and year 2014. This shows that mass activity of buck improved as the frequency of the collection or number of ejaculations increased. Significant effect $(\mathrm{P}<0.001)$ of year on initial motility percentage of sperm was found (Table 2). Highest initial motility of buck semen was found in year 2016 $(81.86 \pm 1.26 \%)$ followed by year $2015(78.55 \pm 0.39 \%)$ and year $2014(77.38 \pm$ $1.23 \%)$.

\section{Effect of season on mass motility and initial motility of sperm}

Season had no effect on mass activity of fresh semen. Average mass activity on wet season was $3.52 \pm 0.10$ followed by dry season $3.46 \pm 0.10$ which was not statistically significant different $(\mathrm{P}=0.367)$. This finding is supported by findings of Mathur et al., (2002) who observed no significant seasonal difference in mass motility and progressive motility. Season had no effect on initial motility of fresh semen. Average initial motility on dry season was $79.41 \pm 0.83 \%$ followed by wet season $79.11 \pm$ $0.83 \%$ which was not statistically significant different $(\mathrm{P}=0.80)$. This finding is also supported by Brito et al., who reported that ambient temperature, month (season) and humidity did not significantly affect sperm production and semen quality probably because there is a little variation in these variables.

\section{Effect of green based forage on mass motility and initial motility of semen}

No significant effect on mass motility and initial motility of semen was found with respect to green based forage feed to different genetic group of bucks. Average mass motility of semen of different buck feed to Napier and maize was $(3.61 \pm 0.08)$ followed by Teosinte (Euchlaena maxicana) $(3.48 \pm 0.11)$ and Oat (Avena sativa) $(3.38 \pm 0.12)$.

\section{Effect of year on concentration and post thaw motility of sperm}

No significant effect of year on concentration $\left(10^{9} / \mathrm{ml}\right)$ of sperm was found (Table $3)$. Highest concentration of sperm of different buck was found in year 2016 (2.43 \pm $0.18)$ followed by year $2015(2.07 \pm 0.05)$ and year $2014(2.03 \pm 0.18)$. Significant effect of year on post thaw motility was found (Table 3 ). Highest post thaw motility percentage was found in the year $2016(57.99 \pm 2.56)$ followed by $2015(57.21 \pm 0.80)$ and $2014(50.35 \pm 2.50)$. This shows that as the age and frequency of semen collection increase there is improvement in the post thaw motility percentage of the sperm. 
Table 2: Least square means and standard errors for mass activity and initial motility of buck semen

\begin{tabular}{|c|c|c|c|c|c|}
\hline Factors & $\begin{array}{c}\text { Number } \\
\text { (n) }\end{array}$ & $\begin{array}{c}\text { LS Mean } \pm \\
\text { SE } \\
\text { mass } \\
\text { motility (\%) }\end{array}$ & $\begin{array}{c}\text { P- } \\
\text { value }\end{array}$ & $\begin{array}{c}\text { LS Mean } \pm \\
\text { SE Initial } \\
\text { motility }(\%)\end{array}$ & P- value \\
\hline Overall mean & 241 & $3.49 \pm 0.07$ & & $79.26 \pm 0.59$ & \\
\hline Year & & & 0.12 & & 0.02 \\
\hline 2014 & 32 & $3.32 \pm 0.15$ & & $77.38 \pm 1.23$ & \\
\hline 2015 & 151 & $3.64 \pm 0.05$ & & $78.55 \pm 0.39$ & \\
\hline 2016 & 58 & $3.51 \pm 0.16$ & & $81.86 \pm 1.26$ & \\
\hline Season & & & 0.68 & & 0.80 \\
\hline Dry (Dec- May) & 109 & $3.46 \pm 0.10$ & & $79.41 \pm 0.83$ & \\
\hline Wet (June-Nov) & 132 & $3.52 \pm 0.10$ & & $79.11 \pm 0.83$ & \\
\hline $\begin{array}{l}\text { Green based } \\
\text { forage }\end{array}$ & & & 0.07 & & 0.83 \\
\hline Teosinte & 89 & $3.48 \pm 0.11$ & & $79.70 \pm 0.92^{b}$ & \\
\hline Oat & 46 & $3.38 \pm 0.12$ & & $78.96 \pm 0.96^{\mathrm{b}}$ & \\
\hline Napier +Maize & 106 & $3.61 \pm 0.08$ & & $79.13 \pm 0.63^{\mathrm{a}}$ & \\
\hline Genetic group & & & 0.10 & & 0.22 \\
\hline Boer $100 \%$ & 44 & $3.20 \pm 0.19$ & & $80.29 \pm 1.49$ & \\
\hline Boer $75 \%$ & 23 & $3.27 \pm 0.10$ & & $78.84 \pm 0.83$ & \\
\hline Boer $50 \%$ & 29 & $3.72 \pm 0.16$ & & $78.61 \pm 1.28$ & \\
\hline Sannen & 53 & $3.47 \pm 0.16$ & & $77.59 \pm 1.24$ & \\
\hline Ajmeri & 39 & $3.80 \pm 0.18$ & & $81.84 \pm 1.47$ & \\
\hline Jamunapari & 53 & $3.48 \pm 0.08$ & & $78.41 \pm 0.67$ & \\
\hline
\end{tabular}




\begin{tabular}{|l|l|l|l|l|c|}
\hline Interactions & & & & & \\
\hline Year x Season & & & 0.10 & & 0.010 \\
\hline $\begin{array}{l}\text { Year x Genetic } \\
\text { group }\end{array}$ & & 0.15 & & 0.14 \\
\hline $\begin{array}{l}\text { Season x Genetic } \\
\text { group }\end{array}$ & & 0.25 & & 0.48 \\
\hline $\begin{array}{l}\text { Green based } \\
\text { forage x Genetic } \\
\text { group }\end{array}$ & & 0.48 & & 0.93 \\
\hline Significant at 5\% $(\mathrm{P}<0.05) ; *$ Significant at $1 \%(\mathrm{P}<0.01) * * *$ Significant at $0.1 \%$
\end{tabular}
$(\mathrm{P}<0.001)$; NS: Non-significant

\section{Effect of genetic group on mass motility and initial motility of semen}

Mass activity and initial motility of fresh semen was different according to different genetic group of bucks. Highest mass activity was found in Ajmeri (3.80 \pm 0.18$)$ followed by Boer 50\% (3.72 \pm 0.16$)$ Jamunapari (3.48 \pm 0.08$)$, Saanen (3.47 \pm 0.16 ), Boer 75\% (3.27 \pm 0.10$)$ and Boer 100\% (3.20 \pm 0.19$)$ had relatively low mass activity. Average mass motility of all breeds was above $60 \%$.

\section{Interaction between different factors on mass motility of the semen}

No significant effect factors on mass motility of the semen were found with interaction between different factors (Year x Season, Year x Genetic group, Season x Genetic group and Feed $x$ Genetic group). Interaction between year and season showed the significant $(\mathrm{P}<0.05)$ effect on initial motility of the semen. Whereas no significant effect was found with the interaction between year and season, year and genetic group, season and genetic group, feed and genetic group.

\section{Concentration of sperms}

Concentration of sperms in fresh semen along with effect of non-genetic factors are presented (Table 3). The overall sperm concentration $\left(10^{\%} / \mathrm{ml}\right)$ in semen of different buck was found to be $2.18 \pm 0.08$. 
Table 3: Least square means and standard errors for concentrations of sperms of buck semen

\begin{tabular}{|c|c|c|c|c|c|}
\hline Factors & $\begin{array}{l}\text { Number } \\
\text { (n) }\end{array}$ & $\begin{array}{l}\text { LS Mean } \pm \text { SE } \\
\text { concentration }\end{array}$ & $\begin{array}{c}\mathrm{P}- \\
\text { value }\end{array}$ & $\begin{array}{c}\text { LS Mean } \pm \\
\text { SE } \\
\text { Post thaw } \\
\text { motility }(\%)\end{array}$ & P-value \\
\hline Overall mean & 241 & $2.18 \pm 0.08$ & & $55.18 \pm 1.19$ & \\
\hline Year & & & 0.18 & & 0.03 \\
\hline 2014 & 32 & $2.03 \pm 0.18$ & & $50.35 \pm 2.50$ & \\
\hline 2015 & 151 & $2.07 \pm 0.05$ & & $57.21 \pm 0.80$ & \\
\hline 2016 & 58 & $2.43 . \pm 0.18$ & & $57.99 \pm 2.56$ & \\
\hline Season & & & 0.16 & & 0.35 \\
\hline $\begin{array}{l}\text { Dry (Dec- } \\
\text { May) }\end{array}$ & 109 & $2.30 \pm 0.12$ & & $54.07 \pm 1.69$ & \\
\hline Wet (June-July) & 132 & $2.06 \pm 0.12$ & & $56.30 \pm 1.68$ & \\
\hline $\begin{array}{l}\text { Green based } \\
\text { forage }\end{array}$ & & & 0.81 & & 0.85 \\
\hline Teosinte & 89 & $2.24 \pm 0.13$ & & $54.62 \pm 1.87$ & \\
\hline Oat & 46 & $2.12 \pm 0.14$ & & $55.94 \pm 1.95$ & \\
\hline Napier +Maize & 106 & $2.17 \pm 0.09$ & & $54.99 \pm 1.28$ & \\
\hline $\begin{array}{l}\text { Genetic group } \\
* * *\end{array}$ & & & 0.003 & & 0.06 \\
\hline Boer 100\% & 44 & $2.24 \pm 0.21^{\mathrm{a}}$ & & $56.93 \pm 3.02$ & \\
\hline Boer $75 \%$ & 23 & $1.99 \pm 0.12^{\mathrm{a}}$ & & $53.27 \pm 1.69$ & \\
\hline Boer 50\% & 29 & $2.37 \pm 0.18^{\mathrm{a}}$ & & $55.05 \pm 2.59$ & \\
\hline Sannen & 53 & $2.27 \pm 0.18^{\mathrm{b}}$ & & $52.38 \pm 2.51$ & \\
\hline Ajmeri & 39 & $2.43 \pm 0.21^{\mathrm{a}}$ & & $54.73 \pm 2.97$ & \\
\hline Jamunapari & 53 & $1.76 \pm 0.09^{b}$ & & $58.75 \pm 1.36$ & \\
\hline
\end{tabular}




\begin{tabular}{|l|l|l|l|l|l|}
\hline Interactions & & & & & \\
\hline Year x season & & & 0.24 & & 0.00 \\
\hline $\begin{array}{l}\text { Year x genetic } \\
\text { group }\end{array}$ & & 0.67 & & 0.14 \\
\hline $\begin{array}{l}\text { Season } \mathrm{x} \\
\text { Genetic group }\end{array}$ & & 0.96 & & 0.48 \\
\hline $\begin{array}{l}\text { Green based } \\
\text { forage } \mathrm{x} \\
\text { Genetic group }\end{array}$ & & 0.89 & & 0.93 \\
\hline
\end{tabular}

* Significant at 5\% $(\mathrm{P}<0.05) ; * *$ Significant at $1 \%(\mathrm{P}<0.01) ; * * *$ Significant at $0.1 \%$ $(\mathrm{P}<0.001)$; NS: Non-significant

\section{Effect of season on concentration and post thaw motility of sperm}

Season had no effect on concentration of sperm. Average concentration $\left(10^{9} / \mathrm{ml}\right)$ of sperm on dry season was $2.30 \pm 0.12$ followed by wet season $2.06 \pm 0.12$ which was not statistically significant different $(\mathrm{P}=0.16)$.

\section{Effect of green based forage on concentration and post thaw motility of sperm}

No significant effect of feed was found on the concentration and post thaw motility of sperm. But highest concentration of sperm was found in buck feed with Teosinte (Euchlaena maxicana) $(2.24 \pm 0.13)$ followed by Napier and maize $(2.17 \pm 0.09)$ and Oat (Avena sativa) $(2.12 \pm 0.14)$.

\section{Effect of genetic group on concentration and post thaw motility of sperm}

High significant effect $(\mathrm{P}<0.003)$ of genetic group on sperm concentration $\left(10^{9} /\right.$ $\mathrm{ml}$ ) was found (Table 3 ). The significant differences in sperm concentration among different genetic group of bucks indicate the genetic potentiality and well adaptability of the different breed in the environment. No significant effect $(\mathrm{P}>0.05)$ of different genetic group of breeds on post thaw motility was found (Table 3). Highest post thaw motility was found in Jamunapari breed $(58.75 \pm 1.36 \%)$, followed by Boer $100 \%(56.93 \pm 3.02 \%)$, Boer 50\% (55.05 $\pm 2.59 \%)$, Ajmeri (54.73 $\pm 2.97 \%)$, Boer $75 \%(53.27 \pm 1.69 \%)$, and Sannen $(52.38 \pm 2.51 \%)$. Dorado et al. (2010) reported that the post thaw progressive motility to be $33.00 \pm 1.02 \%$ while mean post-thaw motility was $56.07 \pm 1.32 \%$ in Florida bucks. Mohammed et al. (2012) reported the significant effect of genetic group on Post-thaw semen motility percentage at $0 \mathrm{hr}$ in Aradi (42.3) and Damascus (39.6) than cross bucks (38.1) which was lower than 
our findings. The average post thaw motility percentage of different genetic group of bucks was above $52 \%$ which is considered as good percentage for the success of the artificial insemination in goat. This satisfaction result might be the use of

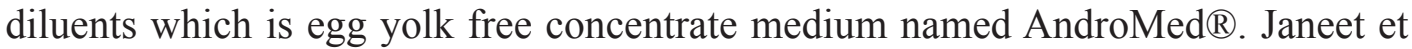
$\mathrm{al} ; 2005$, demonstrate that total and progressive motility (\%) in frozen-thawed semen processed in AndroMed $®(54.4 \pm 3.2$ and $25.5 \pm 2.3)$ were significantly $(\mathrm{P}<0.05)$ higher when compared to TRIS-egg yolk extender (45.9 \pm 2.0 and $14.9 \pm 1.0)$.

\section{Interaction between different factors on concentration and post thaw motility of the semen}

No significant effect on concentration and post thaw motility of the semen was found with interaction between different factors (year and genetic group, Season and genetic group, green based forage and genetic group) but interaction between year and season showed the highly significant effect $(\mathrm{P}<0.001)$ on post thaw motility of semen.

\section{CONCLUSION}

The quality and quantity of semen production is affected by different non genetic factors. The quality and quantity of semen production varies according to the breed. Except on the initial motility and post thaw motility year had no significant effect on volume density, mass motility and concentration of semen among different genetic group of bucks. Similarly season and Green based forage had no significant effect on the quality and quantity parameter of semen of different genetic group of bucks. Significant effect of different genetic group of buck were found on the parameter like volume, density and concentration of semen but there was no association of this factors on the parameter like mass motility, initial motility and post thaw motility. Average Post thaw motility \% of the entire breed maintained at NLBC for semen production was above $52 \%$ which might be the result of diluents that is egg yolk free protein and it might have improved the post thaw motility percentage. The demand of Boer, Jamunapari and Ajmeri semen is high in different district of the country. Large volume of semen from government and non-government sector is imported annually for AI in the country. But NLBC Pokhara has already started production and distribution of semen from the exotic buck of goat. Semen quality and quantity produced and used in Nepal is of good quality and meet the international requirement. Therefore, better management and distribution of quality semen by Government at different DLSO will improve the conception rate and save huge effort and investment for the importation of semen. 


\section{REFERENCES}

Aguiar, G. V., M. F. Van Tilburg, A. G. V. Catunda, C. K. S. Celes, I. C. S. Lima, A. C. N. Campos, and A. A. Araújo. 2013. Sperm parameters and biochemical components of goat seminal plasma in the rainy and dry seasons in the Brazilian Northeast: the season's influence on the cooling of semen. Arquivo Brasileiro de Medicina Veterinária e Zootecnia, 65(1), 6-12pp.

Arredondo, A. J. G., A. G. Gomez, J. F. Vazquez-Armijo, R. A. Ledezma-Torres, H. Bernal-Barragan and F. Sanchez-Davila. 2015. Status and implementation of reproductive technologies in goats in emerging country. African Journal of Biotechnology, 14(9): 719-727pp.

Brito, L.F.C., A.E.D.F. Silva, L.H. Rodrigues, F.V. Vieira, L.A.G. Deragon and J.P. Kastelic, 2002. Effects of environmental factors, age and genotype on sperm production and semen quality in Bos indicus and Bos Taurus A.I bulls in Brazil. Animal Reproduction Science, 70: 181-190pp.

Dorado, J., I. Rodriguez and M. Hidalgo. 2007. Cryopreservation of goat spermatozoa: Comparison of two freezing extenders based on postthaw sperm quality and fertility rates after artificial insemination. Theriogenology 68: 168-77pp.

Dorado, J., A. Munoz-Serrano and M. Hidalgo. 2010. The effect of cryopreservation on goat semen characteristics related to sperm freezability. Animal Reproduction Science (121): 115p.

Elhammali, N. S.; Alqurashi, A. M.; Ibrahim, M.; Elsheikh, A. S. 2013. Puberty of crossbred male goat kids. Journal of American Science, 9(4); 95-99pp.

Elsheikh and Elhammali. 2015. Semen quality of mature crossbred male goats during different seasons. Journal of Agriculture and Veterinary Science (IOSRJAVS), p-ISSN: 2319-2372. Volume 8, Issue 9 Ver. II (Sep. 2015), 01-05pp.

Elsheikh, A. S.; Elhammali, N. S.; Ibrahim, M. T.; Alqurashi, A. M. 2013. Influence of season of birth on pubertal characteristics of male goat kids. JASA, 2(2): 108-111pp.

Mittal, P. K., Anand, M., Madan, A. K., Yadav, S. and Kumar, J. 2014. Antioxidative capacity of vitamin $\mathrm{E}$, vitamin $\mathrm{C}$ and their combination in cryopreserved Bhadawari bull semen. Vet. World. 7(12): 1127-1131pp.

Maina, V. A., Chaudhari SUR, Mshelia, Williams. 2006. Influence of Season on 
Semen Characteristics of Sahel Bucks in Borno State. Journal of Applied Sciences, 6: 353-356pp.

Mathur, A. K., S. Tyagi and S. P. Singh. 2002. Frieswal bull - an experience of HF with Sahiwal. J. Livest. Poultry Prod. 18(1-2): 21-23pp.

Mittal, PK, Anand M, Madan AK, Yadav S, Kumar J 2014. Antioxidative capacity of vitamin $\mathrm{E}$, vitamin $\mathrm{C}$ and their combination in cryopreserved Bhadawari bull semen. Veterinary World, 7(12): 1127- 1131pp.

MoAD. 2012. Ministry of Agricultural Development, Agribusiness Promotion and Statistics Division, Agri Statistics Section, Singhdurbar, Kathmandu Nepal. Statistical Information on Nepalese Agriculture. (Accessed 10 February 2016.)

Mohammad, K. M. 2012. Effect of genetic group, semen diluents and freezing regimens on sperm freezability and goats reproductivity. Assiut Vet. Med. J.Vol 58 No. $135 p$

Mohammed et al 2014. Effect of genetic group, semen diluents and freezing regimens on sperm freezability and goats reproductivity, AssiutVet. Med. J. 58 No. 135 October 2012.

MoLD. 2016. Ministry of Livestock Development. Commitment paper (Nepali). http://www.mold.gov.np/uploads/files/pratibaddata.pdf (Accessed 10 April 2016.).

Sultana, R.2013. Study on buck evaluation based on semen quality and fertility, Bang. Journal Animal Science. 42(2): 101-108pp.

Suyadi, A. 2014. Sexual behaviour and Semen Characteristics of Young Male Boer Goats in Tropical Condition: A Case in Indonesia, International Journal of Biological, Biomolecular, Agricultural, Food and Biotechnological Engineering 6: 6p.

Tardiff A.L., Farrell P.B., Trouern Trend V. and Foote R.H. (1997). Computer assisted sperm analysis for assessing initial semen quality and changes during storage at $5{ }^{\circ}$ C. J. Dairy Science. 80: 1606-1612pp.

Toe, F., Lahlou-Kassi, A., Mukasa-Mugerwa, E., 1994. Semen characteristics of Ilede-France rams of different age and physical condition. Theriogenology 42: 321-326pp. 
Nepalese Vet. J. 35:23- 40

Vilar AC, Barnabe VH, Birgel FH, Barnable RC and Visintin JA (1993). Testis and semen characters in goats reared in a semi-arid area in pariaba state. Revista Brasileira de Reproducao Animal, 17(1- 2):23-32pp.

Vishwanath, R. and S. Shannon .2000. Storage of bovine semen in liquid and frozen state. Anim Reprod Science; 62: 23-53pp. 